\title{
ANTHROPOLOGICAL AND MEDICAL MARKS OF SMOKING BEHAVIOR OF THE ROMANIAN TEENAGERS
}

\author{
Adina Baciu \\ Institute of Anthropology „Francisc I. Rainer” of the Romanian Academy, Bucharest, Romania
}

Summary. The objective of this study is to determine the frequency and the effects of smoking on health and establish the importance of some educational programs for preventing and quitting smoking for teenagers and young people. The cross-sectional study was created in 2011-2012, within the partnership educational projects, No. 357/2011 and 356/2011, the sample comprised 515 subjects ( 228 male, 287 female) from both urban and rural areas, $12-20$ years of age. They were medically and anthropometrically examined and they filled out questionnaires containing 41 items. The results were statistically processed with SPSS version $13.37 .18 \%$ of the participants, of both genres, smoked at least once in a lifetime. $55.17 \%$ of the boys and $65.04 \%$ of the girls first tried a cigarrete between 11 and 16 years of age. $49.70 \%$ of the participants had regular smokers in their families. $37.63 \%$ of the girls and $25.67 \%$ of the boys had consistent smoker parents. The cardio-vascular and digestive illnesses were found in $24.59 \%$ of the participants' family members, these cases all being followed by diabetes and metabolic diseases (22.95\%). $31.71 \%$ of the participants of both genres considered their health status as satisfactory, the acute infections of upper respiratory tract being the most common. Young people start smoking for various reasons. Awareness campaigns are, thus, necessary, in order to popularize the negative effects of smoking on health for both active and passive smokers, passive smokers who are not to be blamed in any case.

Key words: smoking, anthropology, tobacco health, young people, information.

\section{Introduction}

Even though tobacco is considered a soft legalized drug, it is a highly toxic drug, which can lead very quickly (sometimes after smoking two, three cigars) to addiction, and a very tenacious one. The toxic element is nicotine, which installs in the nicotinic receptors for acetylcholine. It is also the element which is responsible for addiction, being significantly "helped" by ammonia and carbohydrates (which produce acetaldehyde), which are used by some of tobacco producers (such as Philip Morris) to increase the effects of nicotine. Tobacco contains over 5300 toxic elements (Rodgman and Thomas, 2008), out of which at least 50 are carcinogenic. Polonium 210, being a radioactive harmful element is also carcinogenic. Tobacco also contains ciahindric acid, well known poison, which has a harmful effect on the cardio-circulatory tract, and acrolein, an ingredient which affects the respiratory mucosa (Bălăceanu et al, 2012).

According to the World Health Organization (WHO), tobacco is the second major cause of death and the fourth most common risk factor for various diseases worldwide (WHO, 2008). According to the WHO Global Status Report on non-communicable disease (NCDs), the European region has the highest overall smoking prevalence rate of $29 \%$ (WHO, 2011). The tobacco products are already responsible for over 1.2 million deaths in Europe each 
year and if effective measures are not taken, the number will increase to 2 million (20\% of the overall deaths until 2020) (World Health Organization, 2002). It is considered that each smoked cigar shortens life for 22 minutes. It is also considered that people who smoke 10 cigars a day shorten their life up to 8 years (Bălăceanu, 2012). More than $75 \%$ of tobacco related deaths will occur in low and middle income countries due to high prevalence of smoking among men (WHO, 2011; Giovino et al., 2012). The estimated burden of NCDs mortality among persons under the age of 60 was more than two times higher in low income countries in comparison with high income countries (29\% vs. 13\%) (WHO, 2011). If they do not quit smoking, 150 million adults who are smokers at this time will die in the following 25 years as a result of smoking. Half of these will lose approximately 20-25 years of their life. Also, it is estimated that 250 millions of children and teenagers will be killed by their own smoking behavior (World Health Organisation, 2001).

The most negative effect is the prevalence of cancer on all of the discussed levels. Lips, mouth and pharynx cancer is 5-9 times more frequent in smokers than non-smokers. The most frequent form of cancer produced by tobacco is pulmonary cancer. Nowadays it is known that $90 \%$ of pulmonary cancer is linked to tobacco smoking and the risk of this type of cancer is $11.4-11.7 \%$ for smokers and only $1.4 \%$ for non-smokers (Villeneuve si Mayo). It is the cause of $61 \%$ of cancer deaths (Bălăceanu, 2012). Smoking has really serious effects on the smokers (active smokers), but also on the non-smokers who stay in the same room (passive smokers). The Environmental Protection Agency from the United States considers that the internal pollution caused by smoking tobacco is carcinogenic; it is put in the same category as the pollution by asbestos, arsenic, benzene or radon (Environmental Protection Agency, 1992).

The health risk profile has three components: the behavioral risk, the social risk and the environmental risk (physique, chemical, biological). The factors of behavioral risks include alimentation, medical drugs consumption, alcohol, tobacco and drugs or habits related to some type of physical activity. These can be highlighted by studies on behaviors and perceptions, problems and health needs, both needs of individuals or a group in a certain population. Objective 12 of the declaration "Health for all in the $21^{\text {st }}$ century" refers to the reduction of the harmful effects of alcohol, drugs and tobacco (session of September 1998 of WHO - the regional committee of Europe). In treating this point, Romania considers the EU legislation, which states that "the purpose of health promotion is to improve the general health standards of community by improving the knowledge on the risk factors and encouraging people to adopt behaviors and healthy life styles. These will be done through information, educative and training measures, in the following areas: nutrition, alcohol consumption, tobacco and drugs, physical exercises, mental health, sexual behavior and medical drugs use" (http://www.snspms.ro/UserFiles/File/ph_press/php_ps_edsan.pdf, p. 4).

Diverse studies have shown that parents can influence their children's behavior regarding smoking through their own example, the way they discuss different aspects linked to smoking and other risk behaviors on health with them, through the social norms they highlight, including allowing smoking in the house for them or other people (Tyas and Pederson, 1998; Huver, 2006; International Union Against Cancer, 2000).

The objectives of this study are:

- To determine the frequency of smoking by age, sex;

- To determine the effects of active and passive smoking on health;

- To highlight the importance of educational programs for preventing or quitting smoking for teenagers. 
The experience of developed countries has proven that, in order to prevent active and passive smoking of teenagers, informational and educative campaigns that play a very important role should be started by parents or teachers and supported by legislative methods to discourage smoking in public areas (Lantz, 2000).

\section{Materials and Methods}

This cross-sectional study is a part of a bigger research and was created in 2011-2012, within the partnership educational projects, No. 357/2011 and 356/2011, the sample comprised 515 subjects, 228 boys and 287 girls, from both urban and rural areas, aged 12-20. The subjects were medically and anthropometrically examined. Ordinal, nominal, binary and scale questionnaires were also applied, referring to health and nutritional status, life style, socio-economic conditions of the subjects and their families; the questionnaires contained 41 items. The statistical analysis was created with the help of SPSS version13, the nonparametric Chi-Square test being the statistical instrument used.

This study follows the ethical standards of scientific research, the inclusion of participants being done with their free and informed consent, and with a written consent in the case of children. During the research the principles of anonymity and confidentiality are followed.

\section{Results}

Table 1 shows that out of 515 subjects participating in the study, 228 were boys, $44.3 \%$ of the total number, and 287 were girls, $55.7 \%$ of the total number.

Table 1. The structure of of the studied subjects based on their gender

\begin{tabular}{lcc}
\hline Gender & Frequency & Percent \\
\hline Male & 228 & 44.3 \\
Female & 287 & 55.7 \\
\hline Total & 515 & 100.0 \\
\hline
\end{tabular}

The table 2 shows that a great number of subjects, of both genres, participating in the study, have smoked at least once in a life time. There is no significant statistical difference between boys and girls.

Table 2. The structure of of the studied subjects based on their gender

\begin{tabular}{lccc}
\hline & \multicolumn{2}{c}{ You have smoked once in your life } & \\
\cline { 2 - 3 } Gender & I have never smoked & Yes & Total \\
\hline Male & 138 & 87 & 222 \\
Female & 183 & 103 & 286 \\
\hline Total & 321 & 190 & 511 \\
\hline
\end{tabular}

The table 3 shows that most of the participant subjects $(55.17 \%$ of the boys and $65.04 \%$ of the girls) first tried a cigarette between 11 and 16 years of age. 
Table 3. The structure of the group depending on gender and age when they smoked a cigarette for the first time

\begin{tabular}{lrrrr}
\hline \multirow{2}{*}{ Age category } & \multicolumn{2}{c}{ Male } & \multicolumn{2}{c}{ Female } \\
\cline { 2 - 5 } & $\mathrm{N}$ & \multicolumn{1}{c}{$\%$} & \multicolumn{1}{c}{$\mathrm{N}$} \\
\hline 5-10 years of age & 23 & 26.43 & 8 & 7.76 \\
$11-16$ years of age & 48 & 55.17 & 67 & 65.04 \\
$17-20$ years of age & 16 & 18.39 & 28 & 27.18 \\
\hline Total & 87 & 100.00 & 103 & 100.00 \\
\hline
\end{tabular}

The table 4 shows that 258 (49.70\%) of the participants in the study had different members of the family who were regular smokers, parents being consistent smokers in 166 of the cases $(32.35 \%)$.

Table 4. The features of the group depending on the regular smokers in their family

\begin{tabular}{lcccccccc}
\hline \multirow{2}{*}{ Gender } & \multicolumn{6}{c}{ What regular smokers do you have in your family } & \\
\cline { 2 - 7 } & parents & $\begin{array}{c}\text { brothers/ } \\
\text { sisters }\end{array}$ & $\begin{array}{c}\text { grand } \\
\text { parents }\end{array}$ & partner & children & No one & Total \\
\hline Male & 58 & 12 & 22 & 4 & 0 & 130 & 226 \\
Female & 108 & 17 & 23 & 10 & 1 & 128 & 287 \\
\hline Total & 166 & 29 & 45 & 14 & 1 & 258 & 513 \\
\hline
\end{tabular}

The tables 5 and 6 show that in $27.4 \%$ of the cases studied there are family members with diverse health conditions or members who died because of certain diseases. The most common were cardio-vascular and digestive conditions (24.59\%), closely followed by diabetes and metabolic conditions $(22.95 \%)$.

Table 5. The structure of the group depending on the health status of the family members of the participants in the study

\begin{tabular}{lccc}
\hline & Frequency & Percent & Valid Percent \\
\hline Yes & 61 & 11.8 & 27.4 \\
No & 100 & 19.4 & 44.8 \\
I don't know & 62 & 12.0 & 27.8 \\
Total & 223 & 43.3 & 100.0 \\
Missing System & 292 & 56.7 & \\
\hline Total & 515 & 100.0 & \\
\hline
\end{tabular}

Table 6. The structure of the group depending on the health status of the family members of the participants in the study

\begin{tabular}{lrr}
\hline Diseases & $\mathrm{N}$ & $\%$ \\
\hline Cardio-vascular conditions & 15 & 24.59 \\
Digestive conditions & 15 & 24.59 \\
Diabetes metabolic conditions & 14 & 22.95 \\
Tumors & 4 & 6.55 \\
Pulmonary conditions & 3 & 4.91 \\
Others & 10 & 16.41 \\
\hline Total & 61 & 100.00 \\
\hline
\end{tabular}


The table 7 shows that a great number of the participants in the study (163, which is $31.71 \%$ of the total) considered that their health status was satisfactory.

Table 7. The features of the group depending on genre and the health status of the participants in the study

\begin{tabular}{lcccc}
\hline Gender & \multicolumn{3}{c}{ You consider your health condition to be } & \multirow{2}{*}{ Total } \\
\cline { 2 - 4 } & good & satisfactory & not very good & \\
\hline Male & 173 & 51 & 4 & 228 \\
Female & 169 & 112 & 5 & 286 \\
\hline Total & 342 & 163 & 9 & 514 \\
\hline
\end{tabular}

\section{Discussion}

Young people with more smoking friends had a greater tendency to smoke and current smokers started smoking with peers (Lim et al., 2006). Peer influence has been identified as a form of social reinforcement (Santrock, 2005). 39.18\% of the boys and $36.01 \%$ of the girls smoked cigarettes during their life (Table 2). The results of the study created by Lotrean and colab. state that a third of the elementary school students have tried smoking at least once, and approximately $8 \%$ smoked the month before the study. In the case of high school students, a third smoked the month before the study (Lotrean and Ionuţ, 2007). In the study of Maher D. Fuad Fuad and colab., the need for complete and integrated strategy to prevent teenage smoking has been highlighted. A comprehensive collaboration between stakeholders in the government, schools and families should be implemented in order to educate the children about the harmful effects of smoking (Maher et al, 2014). The findings of study by Movsisyan and colab. Indicate a critical need for making healthcare providers more prepared and willing to implement smoking cessation interventions in hospital settings (Movsisyan et al., 2012).

According to the table $3,81.60 \%$ of the boys and $72.80 \%$ of the girls first tried to smoke a cigarette before 16 years old, the higher percentage being registered between 11 and 16 years of age; there are no statically significant differences between the two genres $(\mathrm{p}=0.075 \%)$. The data resulted from the study is more extensive than that found in literature, which shows that in 2011, the prevalence of the smoking behavior before 16 years of age was 52\%; there is a decrease in comparison with the past years, as it is shown in the following: in 2007 (54\%), in 2003 (64\%) and in 1999 (57\%). The average registered percent for the participant countries in ESPAD 2011 study is 54\% (ESPAD 2011). Different studies show that if young people do not start smoking before 20 years, it is less possible they will start later and, at the same time, the early start of this behavior is linked to the habit of heavy smoking, a difficulty in quitting and a higher probability of getting sick as a result of smoking (World Health Organisation, 2001).

In the case of the families of the participant, there was a geater number of regular smokers (Table 4). The percentage of parents who smoked in case of girls (37.3\%) is higher than in case of boys $(25.67 \%)$. The questionnaire used by Simić and colab. consisted of items concerning smoking habits, alcohol consumption and physical inactivity. The variable of parents' occupation was arranged into four categories: working-job, administrative-job, agriculture-job, and others. No significant correlation between parents' occupation and examined habits was found (Simić et al., 2008). The study of Lotrean and colab. shows that approximately $61 \%$ of the students in elementary school and $70 \%$ of high school students 
declared that they were exposed to passive smoking in their one home during the last week, and a quarter were passive smokers in their one home daily (Lotrean and Ionuţ, 2007). Murray and colab. Further demonstrate the ways in which passive smoking presents a significant risk to health and well-being of young children. Interventions in preventing second hand exposure to cigarette smoke from parents and other household members therefore remain an urgent priority (Murray, 2012). Tobacco is a harmful element for the cardiocirculator system. Other than functional disorders like tachycardia or hypertension, it starts structural changes of arteries, generating or accelerating and magnifying the processes of atherosclerosis in all vessels. Hence, smoking is a risk factor for angina pectoris and myocardial infarction, strokes and peripheral arteries of legs. It was recently discovered that in the countries where public smoking was prohibited, the number of myocardial infarctions decreased significantly. Smoking harms the efficiency of the immune system, which leads to lower resistance to infections (including SIDA), a decrease of fertility both for men and women and a greater risk of diabetes (Bălăceanu et al., 2012). The most common conditions of the family members of the participants in the study were cardio-vascular conditions and the digestive ones $(24.59 \%)$, followed by diabetes and metabolic diseases $(22.59 \%)$, according to tables 5 and 6. Khan Ajab and colab. show that the cholesterol, triglycerides, HDL-cholesterol, LDL-cholesterol levels of smoking, snuff and both addicted diabetic groups were not significantly changed compared to diabetic control group with p-value > 0.05 respectively. It can be concluded that there is no additional adverse effect of tobacco on the biochemistry of diabetic patients (Khan, 2011).

$31.71 \%$ of the participants in the study, of both genders, considered their health status was a satisfactory (table 7), the acute infections of upper respiratory tract being the most common. Tobacco has a great effect on the oropharyngeal mucosa and a greater one on the bronchial one and on the lungs (Bălăceanu, 2012).

\section{Conclusion}

Young people start smoking for various reasons, sometimes they are encouraged by smoking behavior in their one house or public spaces. They find friends who smoke and they are exposed to active smoking and to the smoke from cigarettes of other people.

The consequences of smoking are serious for health, they are visible and they contribute to the shortening of a life spam.

Awareness campaigns are necessary for young people, in order for them to realize the harmful effects of smoking on health of both active and passive smokers. Media play an important role in educating people about the serious risks of active and passive smoking and on defending the rights of non-smoking young people to breathe clean, smoke free air. Developing educational programs for preventing smoking of teenagers and promoting quitting smoking of teenagers who already smoke are absolutely necessary.

Also, there is a need for policies and regulations which would ensure that young people live in a healthier environment by restricting production and distribution of tobacco. 


\section{References}

Bălăceanu Stolnici C, Papari CA, Papari A, Cozaru GC, Iamandescu I.-B. Tentaţie şi dependenţă. Constanţa: Editura Fundaţiei "Andrei Şaguna". 2012: 183-188.

Environmental Protection Agency. Respiratory Health Effects of Passive Smoking: Lung Cancer and Other Disorders. Washington, DC: Environmental Protection Agency. 1992.

Giovino GA, Mirza SA, Samet JM, Gupta PC, Jarvis MJ, Bhala N, Peto R, Zatonski W, Hsia J, Morton J, Palipudi KM, Asma S, Tobacco use in 3 billion individuals from 16 countries: an analysis of nationally representative cross-sectional household surveys. Lancet. 2012; 380(9842): 668-679.

Huver RME, Engels R, De Vries H. Are anti-smoking parenting practices related to adolescent smoking cognitions and behavior? Health Educ. Res. 2006; 21: 66 - 77.

International Union Against Cancer. Youth and Tobacco. UICC Fact Sheet 11. Geneva: International Union Against Cancer. 2000.

Khan A, Malik SA, Khan AA, Ahmad A, Ali R. Effects of tobacco (smoking and snuffing) in type 2 diabetic patients. International Journal of Food Safety, Nutrition and Public Health, 2011; 4(24):196-204.

Lantz MP. Investing in youth tobacco control: a review of smoking prevention and control strategies. Tobacco Control. 2000; 9:47-63.

Lim KH, Amal NM, Hanjeet K, Mashod MY, Wan Rozita WM, Sumarni MG, Hadzrik NO. Prevalence and factors related to smoking among secondary school students in Kota Tinggi District, Johor, Malaysia. Trop Biomed. 2006; 23(1): 75-84.

Lotrean L, Ionuţ C, De Vries H. Fumatul activ şi pasiv în rândul elevilor de liceu şi şcoală generală. Revista de Igienă şi Sănătate Publică (Journal of Hygiene and Public Health). 2007; 57(2):24-31.

Maher D. Fuad F, Ahmad F, Balsam MNA, Nawwar GI, Azizi A. Smoking among Malay Upper Secondary School Students in Shah Alam, Selangor, Malaysia. International Journal of Collaborative Research on Internal Medicine \& Public Health. 2014; 6(1): 23-28.

Movsisyan KN, Petrosyan V, Harutyunyan A, Petrosyan D, Muradyan A, Stillman AF. Smoking behavior, attitudes, and cessation counseling among healthcare professionals in Armenia. BMC Public Health 2012; 12:1028 doi:10.1186/1471-2458-12-1028.

Ministerul Afacerilor Interne, Agenţia Naţională Antidrog. Studiul naţional în şcoli privind consumul de tutun, alcool şi droguri (ESPAD 2011).

Murray RL, Britton J, Leonardi-Bee J. Second hand smoke exposure and the risk of invasive meningococcal disease in children: systematic review and meta-analysis. BMC Public Health. 2012; 12:1062 doi:10.1186/1471-2458-12-1062.

Rodgman A, Perfetti TA. The Chemical Components of Tabacco and Tabacco Smoke. CRC Press. 2008.

Santrock J. Adolescence (10th eds): McGraw-Hill: Boston: 2005.

Simić S, Božić-Krstić V, Pavlica T, Rakić R. Frequency of some habits among yoth regarding their parents' occupation. Glasnik Antropološkog društva Srbije. 2008;43:122-126.

Tyas LS, Pederson L. Psychosocial factors related to adolescent smoking: a critical review of the literature. Tobacco Control. 1998; 7:409-420.

WHO: WHO report on the global tobacco epidemic, 2008: the MPOWER package. Geneva: World Health Organization; 2008.

WHO: Global status report on noncommunicable diseases 2010. Geneva: World Health Organization; 2011.

World Health Organisation. The European Report on Tobacco Control Policy. Copenhagen: WHO Regional Office for Europe. 2002.

World Health Organisation. Tabacco-free youth: A life skills primer. Scientifical and Technical publication No. 579, Washington DC: WHO 2001.

Promovarea sănătăţii şi educaţie pentru sănătate. Available at: http://www.snspms.ro/UserFiles/File/ph_press/php_ps_edsan.pdf. Accessed on April 6. 2014. 


\section{ANTROPOLOŠKI I MEDICINSKI POKAZATELJI PUŠAČKOG PONAŠANJA KOD RUMUNSKIH TINEJDŽERA}

Adina Baciu

Sažetak. Cilj ove studije bio je utvrditi učestalost i uticaj pušenja na zdravlje kao i uvideti značaj edukativnih programa za prevenciju i prestanak pušenja kod tinejdžera i mladih ljudi. Studija preseka nastala je u periodu 2011-2012., u okviru partnerskog edukativnog programa, br. 357/2011 i 356/2011. Uzorkom je obuhvaćeno 515 ispitanika (228 muškog pola i 287 ženskog pola) iz urbanih i ruralnih oblasti, uzrasta 12-20 godina. Ispitanici su sagledani medicinski i antropometrijski. Ispitanici su takođe popunili upitnik koji se sadrži 41 stavku. Rezultati su statistički obrađeni pomoću SPSS verzije 13.37, 18\% ispitanika oba pola pušilo je barem jednom u životu. $55,17 \%$ dečaka i $65,04 \%$ devojčica prvu cigaretu ispušilo je na uzrastu između 11 i 16 godina. 49, 70\% ispitanika imalo je aktivne pušače u porodici. $37,63 \%$ devojčica i $25,67 \%$ dečaka imalo je aktivne pušače za roditelje. Kardiovaskularne bolesti i bolesti digestivnog trakta zabeležene su kod $24,59 \%$ članova porodica ispitanika, svi slučajevi praćeni su dijabetesom i bolestima metabolizma (22,95\%). $31,71 \%$ ispitanika okarakterisalo je svoje zdravstveno stanje kao zadovoljavajuće, akutne infekcije respiratornog trakta bile su najčešće. Mladi ljudi počinju da puše iz različitih razloga. Kampanje za podizanje svesti ljudi potrebne su kako bi se ukazalo na negativne efekte pušenja na zdravlje kod aktivnih i pasivnih pušača, kod pasivnih pušača koje ni u kom slučaju ne možemo kriviti.

Ključne reči: pušenje, antropologija, duvan, zdravlje, mladi ljudi, informacije 